\title{
Detection of caseinophosphopeptides in the distal ileostomy fluid of human subjects
}

\author{
H. Meisel ${ }^{1}$, H. Bernard ${ }^{2}$, S. Fairweather-Tait ${ }^{3}$, R. J. FitzGerald ${ }^{4}$, R. Hartmann ${ }^{1}$, \\ C. N. Lane ${ }^{5}$, D. McDonagh ${ }^{5}$, B. Teucher ${ }^{3}$ and J. M. Wal ${ }^{2}$ \\ ${ }^{1}$ Federal Dairy Research Centre, Institute for Dairy Chemistry and Technology, Kiel, Germany \\ ${ }^{2}$ Laboratoire d'Immuno-Allergie Alimentaire, INRA-CEA, SPI, Gif sur Yvette, France \\ ${ }^{3}$ Institute of Food Research, Norwich Research Park, Norfolk, UK \\ ${ }^{4}$ University of Limerick, Life Sciences Department, Limerick, Republic of Ireland \\ ${ }^{5}$ Teagasc, Dairy Products Research Centre, Moorepark, Fermoy, Co. Cork, Republic of Ireland
}

(Received 23 April 2002 - Revised 16 October 2002 - Accepted 31 October 2002)

\begin{abstract}
Caseinophosphopeptides (CPP) were detected for the first time in ileostomy fluid, collected at $2 \mathrm{~h}$ intervals for $10 \mathrm{~h}$ post milk and CPP ingestion, from human volunteers with an ileostomy. The level of CPP present in ileostomy fluid obtained from milk-fed volunteers was markedly higher than that from volunteers fed with selected CPP preparations. The findings are based on HPLC analysis in combination with peptide-bound P determination, thin-layer electrophoresis and amino acid analysis, together with ELISA studies using polyclonal antibodies raised against a set of CPP to detect immunoreactive CPP in ileostomy fluid. These procedures allowed the detection of $\mathrm{nM}$ concentrations of CPP. CPP, which can be released during intestinal digestion, may function as bioactive constituents and carriers for different minerals, especially $\mathrm{Ca}$, and may be used as ingredients in functional foods or pharmaceutical preparations.
\end{abstract}

Caseinophosphopeptides: Milk: Human ileostomy samples: Bioactive peptides

Food-derived bioactive peptides represent a source of health-enhancing components that may be incorporated in functional foods and in pharmaceutical preparations. These peptides are potential modulators of various regulatory processes in the body. Milk proteins are precursors of many different biologically active peptides, e.g. peptides having opioid, hypotensive (angiotensin-converting enzyme inhibitory), immunomodulating or antimicrobial activities (for reviews, see Meisel, 1997, 2001; FitzGerald \& Meisel, 2000; Meisel \& FitzGerald, 2000). The intrinsic bioactivities of the peptides encrypted in major milk proteins are latent until they are released and activated by enzymatic hydrolysis, e.g. during gastrointestinal digestion and/or food processing. Several studies have been performed in the last two decades on caseinophosphopeptides (CPP), which may function as carriers for different minerals, especially $\mathrm{Ca}$ (for review, see FitzGerald, 1998). It has been proposed that CPP, which form soluble complexes with $\mathrm{Ca}_{3}\left(\mathrm{PO}_{4}\right)_{2}$ in vitro, may lead to enhanced $\mathrm{Ca}$ absorption by limiting the precipitation of $\mathrm{Ca}$ at alkaline conditions pertaining in the distal ileum. However, until now it had not been established whether CPP can be obtained in the human ileum following digestion of a milk meal (Meisel et al. 2001). For their function as mineral carriers CPP must, at least partially, resist enzymatic digestion during intestinal passage. In the present study (see also Meisel et al. 2001), intestinal fluid samples obtained from human subjects during feeding trials with milk and selected CPP preparations were analysed for the presence of CPP.

\section{Material and methods}

\section{Milk and caseinophosphopeptide preparations}

The same brand of a fresh pasteurized, homogenized full-fat cows' milk was obtained from a local food retailer for the duration of the present study. CPP were generated as previously described (McDonagh \& FitzGerald, 1998) from bovine sodium caseinate, which was hydrolysed with four different commercially available food-grade proteinase preparations, i.e. PTN 3.0S and Alcalase (both obtained 
from Novo Nordisk, Novo Alle, Bagsvaerd, Denmark), Bioprotease $\mathrm{P}$ (conc) (Quest International, Carrigaline, Cork, Republic of Ireland) and Proteinase DS (RhônePoulenc, Stockport, Cheshire, UK), resulting in CPP preparations designated CPP1, CPP2, CPP3 and CPP4 respectively. CPP were aggregated by inclusion of $\mathrm{Ca}$ (Adamson \& Reynolds, 1995) and the resultant aggregates were collected by ultrafiltration through $10 \mathrm{kDa}$ cut-off membranes (Brule, 1982; McDonagh \& FitzGerald, 1998). The CPP preparations were decalcified (McDonagh \& FitzGerald, 1998) prior to spray-drying. The N:P for these different preparations were: $3 \cdot 11: 1 \cdot 00,3 \cdot 15: 1 \cdot 00,4 \cdot 0: 1 \cdot 00$, and 3.59:1.00 respectively. All four preparations had $>90 \%$ peptide materials with a molecular mass $<1 \mathrm{kDa}$.

\section{Ileostomy study}

One male and three female volunteers with an ileostomy participated in the present study. The mean age of the volunteers was 51.5 (SD 7.9) years. All four volunteers were without any acute digestive problems and were taking routine antacid medication to help digestion; no medication was taken during the experimental days. The study protocol was approved by the Norfolk (UK) District Ethics Committee and informed consent was obtained from each volunteer prior to participation. Volunteers were chosen on the basis that they had no prior history of adverse reactions to the consumption of milk proteins. Cytochemical assessment of CPP in vitro (Caco-2 cells) revealed no cytotoxic potential, and no adverse influence on epithelial properties and differentiation (Hartmann \& Meisel, 2002).

In the present study, which was carried out within 2 months, each volunteer consumed either $250 \mathrm{~g}$ full-fat cows' milk or one of four different CPP preparations $(1.52 \mathrm{~g}$ in $20 \mathrm{ml}$ water), together with a standard milk-protein-free breakfast, on two separate occasions following an overnight fast. Ileostomy fluid was collected at baseline ( $t 0)$ after a $10 \mathrm{~h}$ overnight fast and following the test meal in $2 \mathrm{~h}$ intervals for $10 \mathrm{~h}(t 1-5)$. The two tests were separated by at least 2 weeks. To avoid consumption of milk products, volunteers were provided with a diet free of milk protein for $2 \mathrm{~d}$ prior to both test days. During the $10 \mathrm{~h}$ experimental period, volunteers were confined to the premises of the Human Nutrition Unit at the Institute of Food Research (Norwich, Norfolk, UK). The same milk-protein-free lunch was provided for all volunteers throughout the study. Ileostomy fluid was immediately centrifuged at $5000 \mathrm{~g}$ for $10 \mathrm{~min}$ at $4^{\circ} \mathrm{C}$ after collection and the pellet and supernatant fractions were stored at $-18^{\circ} \mathrm{C}$ prior to freeze-drying. According to the volunteer and the meal ingested, the ileostomy samples were designated as 01-1:CPP2, 01-2:Milk, 02-1:CPP4, 02-2:Milk, 03-1:Milk, 03-2:CPP1, 04-1:Milk, 04-2:CPP3.

\section{Extraction of ileostomy samples}

Addition of perchloric acid prevented the degradation of CPP by proteolytic and/or peptideolytic action in reconstituted ileostomy samples, presumably by inhibition of enzymes of intracellular or bacterial origin, which may be liberated after freezing and thawing (D McDonagh,
H Meisel, C Lane and RJ FitzGerald, unpublished observations). Lyophilized ileostomy sample (100 mg) was suspended in $2 \mathrm{ml}$ perchloric acid (172 mM, $\mathrm{pH} 1.2$ in the final extract). The suspension was vortexed vigorously for $1 \mathrm{~min}$ and then treated in an ultrasonic bath for $3 \mathrm{~min}$. After centrifugation at $14000 \mathrm{~g}$ for $3 \mathrm{~min}$, the perchloric acid-soluble portion of ileostomy samples was used for further analyses. Ileostomy samples, which had been collected at various time intervals $(t 1-5)$, were pooled for analysis of CPP in order to maximize the likelihood of detecting CPP.

\section{Adsorptive microconcentration}

Microcon strong cation exchange (SCX) units (Amicon, Inc., Beverly, MA, USA) containing a SCX membrane were used for adsorptive microconcentration of phosphopeptides. The manufacturer's protocol was followed with minor modifications. To wet the membrane, $0.5 \mathrm{ml}$ methanol and then $0.5 \mathrm{ml}$ water were centrifuged at $7000 \mathrm{~g}$ for $15 \mathrm{~s}$ through the SCX unit. Sample $(4 \times 0.5 \mathrm{ml})$ was loaded into the SCX unit. The filtrate (SCX-A) obtained after centrifugation at $1200 \mathrm{~g}$ for $10-30 \mathrm{~min}$ was collected for further analyses. Thereafter, the membrane was washed with $10 \mathrm{mM}-\mathrm{HCl}$ to remove residual contaminants. For elution of adsorbed peptides, $50 \mu \mathrm{l}$ desorption reagent $\left(0.5 \mathrm{ml}\right.$ methanol, $0.1 \mathrm{ml} \mathrm{NH}_{3}(250 \mathrm{ml} / \mathrm{l}), 0.4 \mathrm{ml}$ water $)$ was pipetted into the unit and was then centrifuged at $14000 \mathrm{~g}$ for $1 \mathrm{~min}$; this step was repeated once and the respective filtrates (microconcentrate SCX-B) were combined for further analyses.

\section{Analytical and semi-preparative reverse-phase HPLC}

The reverse-phase HPLC-system consisted of two 422 Master pumps (Bio-Tek Kontron, Neufahrn, Germany), two mixers M800 (Bio-Tek Kontron), injector 7125 (Rheodyne, Rohnert Park, CA, USA), column oven (constructed by the authors), diode array detector 440 (Bio-Tek Kontron), Foxy fraction collector (ISCO, Lincoln, NE, USA) and data system KromaSystem 2000 (Bio-Tek Kontron). A LiChroCART Supersphere $100 \mathrm{C}_{18}$ endcapped $124 \times$ $4 \mathrm{~mm}$ column (16855; Merck, Darmstadt, Germany) was used for analytical and semi-preparative separations; column temperature was $30^{\circ} \mathrm{C}$. Solvent A was trifluoroacetic acid ( $1 \mathrm{ml} / \mathrm{l}$ water) and solvent $\mathrm{B}$ was trifluoroacetic acid $(1 \mathrm{ml} / \mathrm{l}$ aqueous acetonitrile $(500 \mathrm{ml} / \mathrm{l}))$. Both solvents were purged with He. Freeze-dried samples were taken up in eluent A. Sample solutions $(100 \mu \mathrm{l}$ extracted material from $100 \mathrm{mg}$ freeze-dried powder reconstituted in $2 \mathrm{ml}$ perchloric acid) were injected and eluted at a flow rate of $1 \mathrm{ml} / \mathrm{min}$. The gradient used was $50 \mathrm{ml} \mathrm{B} / 1$ for $5 \mathrm{~min}$ and $50-900 \mathrm{ml} \mathrm{B} / \mathrm{l}$ in $85 \mathrm{~min}$. For rechromatography, a shallower gradient $(50 \mathrm{ml} \mathrm{B} / 1$ for $5 \mathrm{~min}$ and 50 to $450 \mathrm{ml} \mathrm{B} / 1$ in $80 \mathrm{~min}$ ) was used. Peaks were detected by absorbance at 215,235 and $280 \mathrm{~nm}$. Peptide fractions were collected and solvents were removed by freeze-drying (Speed Vac concentrator; Savant, Holbrook, NY, USA). 


\section{Determination of phosphorus content}

$\mathrm{P}$ content was measured after wet ashing of freeze-dried samples, which converts organic $\mathrm{P}$ to inorganic phosphate. Inorganic phosphate was quantified as the phosphomolybdate complex by an ultramicro method (Meisel \& Frister, 1988).

\section{Amino acid analysis}

Freeze-dried samples were hydrolysed with $6 \mathrm{M}-\mathrm{HCl}-$ phenol $(10 \mathrm{ml} / \mathrm{l})$ in evacuated tubes at $110^{\circ} \mathrm{C}$ for $24 \mathrm{~h}$. Amino acid analysis was performed with an Alpha Plus analyser (type 4151; Amersham Pharmacia Biotech, Freiburg, Germany) using an Ultrapac 8 ion-exchange resin (80202845; Amersham Pharmacia Biotech) and sodium citrate buffer system (Amersham Pharmacia Biotech). SerP content per mg lyophilized ileostomy sample was obtained by extrapolation of the SerP concentration in acidic hydrolysates $(6,12,24 \mathrm{~h})$ to zero time. Calibration was achieved by running a mixture of standard amino acids (AA-S18; Sigma, St Louis, MO, USA) and SerP (Sigma) respectively.

\section{Thin-layer electrophoresis}

Thin-layer electrophoresis was performed using a thin-layer electrophoresis double chamber connected to a mains supply unit 1200/200 (DESAGA, Heidelberg, Germany). Samples $(5-10 \mu \mathrm{l})$ of acidic hydrolysates $(t 3)$ of ileostomy samples were dotted on microcrystalline cellulose sheets (Polygram CEL 400, $0.20 \times 0.20 \mathrm{~m}, 0.1 \mathrm{~mm}$ thickness; Macherey-Nagel, Düren, Germany); an additional set of the same samples were spiked with a SerP solution $(5 \mathrm{nmol} / 0.5 \mu \mathrm{l}$ water). Separations were carried out in pyridine-acetic acid-water (5:50:945, by vol.), $\mathrm{pH} 3 \cdot 5$, at $400 \mathrm{~V} / 15-20 \mathrm{~mA}$ for $1 \mathrm{~h}$. Components of the partial hydrolysates were detected by spraying with a solution of ninhydrin $(0.1 \mathrm{mg} / 50 \mathrm{ml}$ methanol $)$ and heating for $5 \mathrm{~min}$ at $110^{\circ} \mathrm{C}$

\section{Preparation and purification of a synthetic phosphopeptide}

A consensus phosphopeptide with a sequence of VESL $\Sigma \Sigma$ $\Sigma$ EESIL ( $\Sigma$ depicts SerP residues) was synthesized using a Milligen 9050 apparatus (Biosearch Inc., Novato, CA, USA) and standard solid-phase synthesis by the 9-fluorenylmethoxycarbonyl continuous-flow method. Synthetic peptide was purified by successive anion-exchange chromatography using a fast protein liquid chromatography system with a mono Q HR 10/10 column (Amersham Pharmacia Biotech), and reverse-phase HPLC using a Waters system (Milford, MA, USA) and a 300 A $\mathrm{C}_{18}$ Vydac column $(250 \times 10 \mathrm{~mm}$; Shandon, France).

\section{Immunogen preparation}

Tryptic CPP isolated by $\mathrm{Ca}^{2+}$-ethanol precipitation from whole casein were coupled to keyhole lympet (megatura crenulata) haemocyanin via its amino groups, using glutaraldehyde. Briefly, $5 \mathrm{mg}$ CPP and $20 \mu \mathrm{l}$ glutaraldehyde were successively added to $10 \mathrm{mg}$ keyhole lympet haemocyanin dissolved in $10 \mathrm{ml} 0.1 \mathrm{M}$-phosphate buffer, $\mathrm{pH} \mathrm{7.4.} \mathrm{After}$ $18 \mathrm{~h}$ stirring at $4^{\circ} \mathrm{C}$, the mixture was divided into $1 \mathrm{ml}$ portions and stored at $-20^{\circ} \mathrm{C}$.

\section{Immunization}

Anti-whole CPP antisera was obtained by immunizing adult male white Blanc-de Bouscat rabbits as follows: $1 \mathrm{ml} \mathrm{immu-}$ nogen solution $(250 \mathrm{ml} / \mathrm{l}$ water) was emulsified with $1 \mathrm{ml}$ Freund's complete adjuvant and injected subcutaneously into two rabbits (no. 1494 and no. 1495). Booster injections were given 6 weeks later and once per month thereafter. Rabbits were bled $10 \mathrm{~d}$ after each immunization. Sera were stored at $4^{\circ} \mathrm{C}$ after addition of sodium azide $(0 \cdot 1 \mathrm{~g} / \mathrm{l})$.

\section{Enzymatic tracer preparation}

Enzymatic tracer was prepared by covalent linkage of consensus synthetic phosphopeptide to the tetrameric form of acetylcholinesterase. This method involved the reaction of thiol groups introduced into phosphopeptide using $N$-succinimidyl- $S$-acetyl-thioacetate with maleimido groups previously incorporated into acetylcholinesterase with $N$-succinimidyl-4-(maleido-methyl)-cyclohexane-1carboxylate as previously described (Caruelle et al. 1988).

\section{Competitive enzyme immunoassay}

All the dilutions were performed in enzyme immunoassay (EIA) buffer corresponding to $0 \cdot 1 \mathrm{M}$-potassium phosphate $\mathrm{pH} 7 \cdot 4$, containing $0.15 \mathrm{~mol} \mathrm{NaCl} / 1,1 \mathrm{~g}$ bovine serum albu$\mathrm{min} / \mathrm{l}$ and $0 \cdot 1 \mathrm{~g}$ sodium azide/l. Competitive EIA were performed using ninety-six-well microtitre plates coated with mouse monoclonal anti-rabbit immunoglobulin $\mathrm{G}(10 \mu \mathrm{g} /$ $\mathrm{ml} 50 \mathrm{~mm}$-phosphate buffer, $\mathrm{pH} 7.4$ for $18 \mathrm{~h}$ at $4^{\circ} \mathrm{C}$ before saturating with EIA buffer), in order to ensure separation of bound and free moieties of the enzymatic tracer during the immunological reaction. The total volume of the immunological reaction was $150 \mu \mathrm{l}$, each component (enzymatic tracer, rabbit polyclonal antisera and standard or sample) being added in a volume of $50 \mu$ l. The enzymatic tracers were used at a concentration of 2 Ellman units/ml (Ellman et al. 1961), while the working dilutions for the corresponding rabbit antisera were previously determined by serial dilution experiments. After $4 \mathrm{~h}$ incubation at $20^{\circ} \mathrm{C}$, the plates were washed (with $0.01 \mathrm{M}$-phosphate buffer $\mathrm{pH} 7.4$ containing $0.5 \mathrm{ml}$ Tween 20/l) before the enzyme activity of the bound immunological complex was quantitated by addition of $200 \mu \mathrm{l}$ Ellman's reagent $\left(7.5 \times 10^{-4} \mathrm{M}\right.$ acetylthiocholine iodide, substrate; $5 \times$ $10^{-4} \mathrm{M} 5,5^{\prime}$-dithiobis(2-nitrobenzoic acid), reagent for thiol colorimetric measurement) per well. After 1 or $2 \mathrm{~h}$ of gentle shaking in the dark at room temperature, the absorbance of each well at $414 \mathrm{~nm}$ was measured using an automatic plate reader. Results were expressed in terms of $\mathrm{B} / \mathrm{B} 0(\%)$ as a function of the dose (logarithmic scale), where B and B0 represent the bound activity in the presence or absence of competitor respectively. All measurements for standards or samples were made in duplicate, and in quadruplicate for B0 values. A linear $\log$-logit transformation was used to fit the standard 
curve. The assay sensitivity was characterized by the dose of standard inducing a $50 \%$ reduction of the binding observed in absence of competitor (B/B0 50\%). The minimum detectable concentration corresponds to an $80 \%$ reduction of the binding (B/B0 $80 \%)$.

\section{Results}

\section{(Phospho)peptide pattern of human ileostomy fluid}

The peptide profiles of ileostomy extract samples pooled over the time points $t 1-5$ were quite similar between one subject and another (four volunteers with an ileostomy), and were largely independent of the test meal ingested, i.e. milk or CPP (Fig. 1). From the HPLC profiles of the different ileostomy fluid samples, no distinctive peptide could be assigned to a component or digestion product of the ingested milk and CPP preparations. The chromatograms measured in the fasting state $(t 0)$ also revealed complex but different patterns (results not shown) as compared with those that were obtained 2 to $10 \mathrm{~h}$ post-dose $(t 1-5)$.

Using HPLC analysis in combination with the determination of organically bound $\mathrm{P}, \mathrm{CPP}$ were found in the perchloric acid-soluble peptide fraction of ileostomy samples obtained from volunteers who ingested milk (Fig. 2, Table 1). However, no CPP were detected in ileostomy samples of volunteers fed specific CPP preparations or in pre-meal samples collected before ingestion of a test meal $(t 0)$. This observation also pertained even if adsorptive (SCX) microconcentration was applied as an additional

(A)

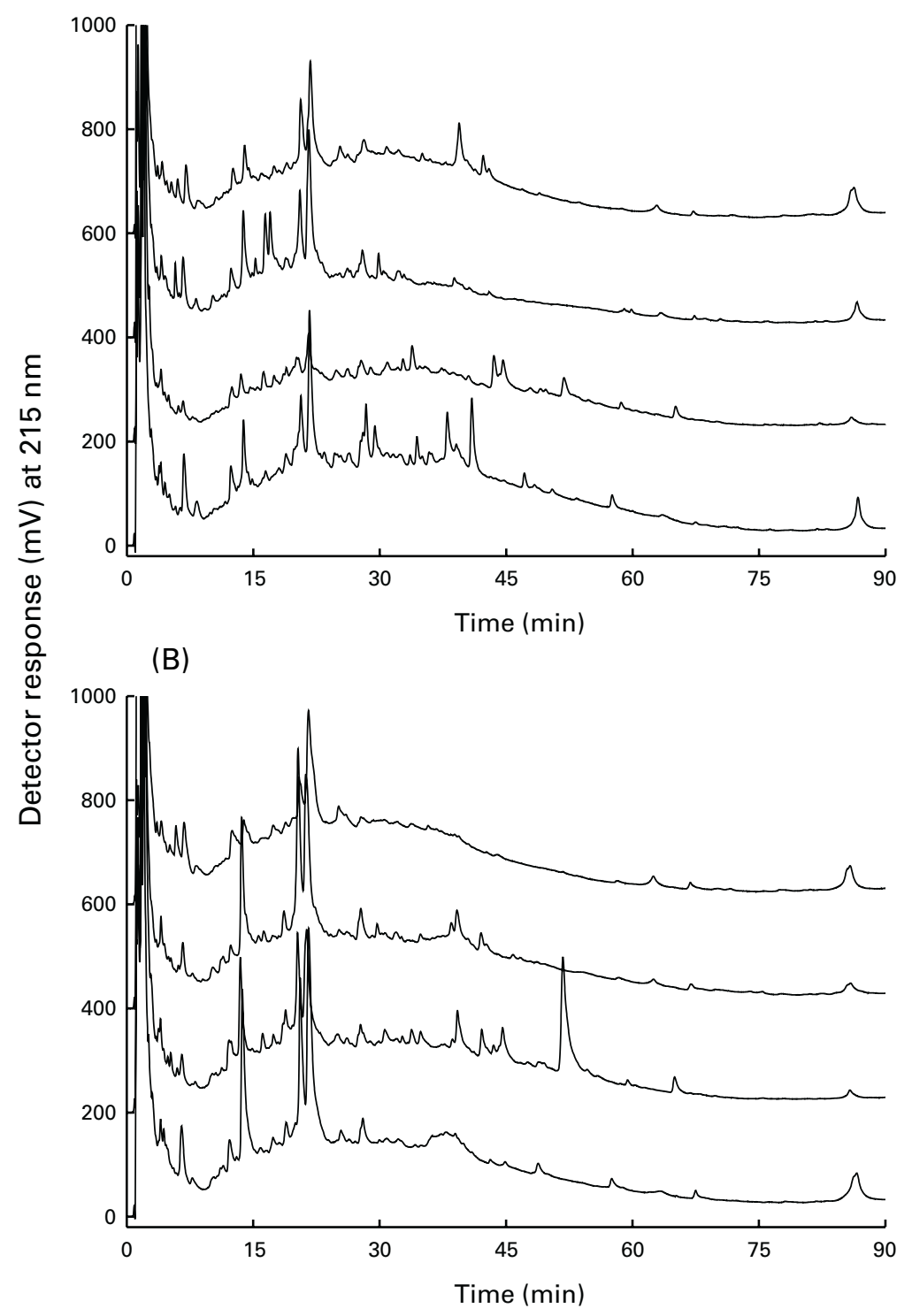

Fig. 1. HPLC peptide patterns of ileostomy fluids collected for $10 \mathrm{~h}$ post-dose at $2 \mathrm{~h}$ intervals (pooled over the time points $t 1-5)$ from four human volunteers after ingestion of a milk meal (A) and caseinphosphopeptides (CPP) meal (B). Test sample reverse-phase HPLC profiles were overlaid for direct comparison purposes. The magnitude of the detector response for all samples was similar. For details of subjects and test meals, see p. 352. (A), patterns represent (vertically, from top) 01-2:Milk, 02-2:Milk, 03-1:Milk, 04-1:Milk; (B), 01-1:CPP2, 02-1:CPP4, 03-2:CPP1, 04-2:CPP3 (for details of sample classification, see p. 352). 
(A)

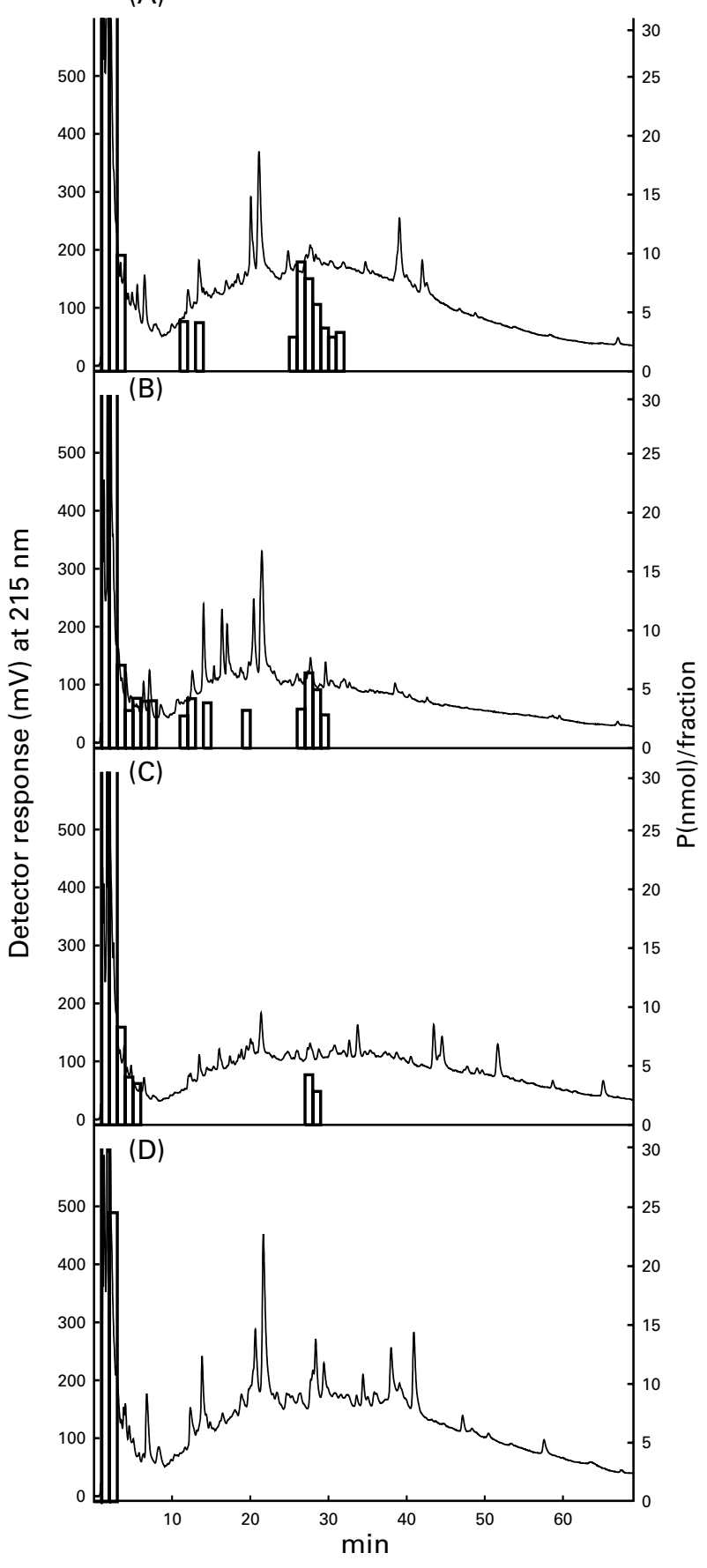

Fig. 2. HPLC peptide pattern and $P$ content of ileostomy fluid (perchloric acid-soluble fraction) collected for $10 \mathrm{~h}$ post-dose at $2 \mathrm{~h}$ intervals (pooled over the time points $t 1-5$ ) from four human volunteers after ingestion of a milk meal. Elution of inorganic $P$ in fractions 1-5, organic (peptide-bound) in fractions $>5$. For details of subjects and test meals, see p. 352. (A), 01-2:Milk; (B), 02-2:Milk; (C), 03-1:Milk; (D), 04-1:Milk (for details of sample classification, see p. 352).

step to enrich for CPP. In earlier experiments, adsorptive microconcentration (SCX) enabled the enrichment of CPP from ileostomy extract spiked with pure phosphopeptides. Non-phosphorylated peptides were also enriched to some extent, but the concentration of CPP (measured by peak area) was more than 7 -fold greater in the corresponding microconcentrate. Therefore, the use of adsorptive microconcentration for the enrichment of CPP from intestinal chyme may compensate for the 3-to 5-fold dilution of the meal within the intestine (Borgström, 1957).

The results from HPLC analysis showing the presence of CPP in ileostomy fluid were confirmed by thin-layer electrophoresis as a specific qualitative method to detect SerP in hydrolysates of ileostomy samples as well as by quantitative amino acid analysis to measure the SerP content (Table 1).

The composition of the CPP in intestinal fluid changed with time post-dose following ingestion of milk (Fig. 3), and the amount of CPP decreased after prolonged digestion $(\geq 8 \mathrm{~h})$. An increase in total peak area and number of peaks after more than $6 \mathrm{~h}$ (e.g. $t 4$ in Fig. 3) may be due to digestion of lunch, which was taken $3 \mathrm{~h}$ after ingestion of the meals (milk or CPP preparation).

\section{Immunoreactive caseinophosphopeptides in human ileostomy fluid}

The EIA system has been developed using specific rabbit polyclonal antibodies raised against a mixture of CPP prepared by tryptic hydrolysis of whole casein and an acetylcholinesterase-labelled synthetic phosphopeptide. This test system appears to be sensitive, allowing a range of detection between 1 and $10 \mathrm{nmol} / \mathrm{ml}$ depending on the polyclonal antibodies used. The binding of acetylcholinesterase-labelled synthetic phosphopeptide to rabbit antibodies was easily inhibited by CPP preparations, e.g. CPP1, 2, 3 and 4, which presented similar inhibition values. Moreover, no differences were observed in the inhibition curves between CPP preparations with or without perchloric acid extraction. The EIA system was then applied to detection of CPP in ileostomy samples (Fig. 4). The validity of the competitive EIA system was supported by the very good agreement in the results obtained with anti-CPP antibodies obtained from two animals (rabbits no. 1494 and no. 1495). Pre-meal $(t 0)$ ileostomy extract samples displayed some low inhibitory effects at a 1:5 dilution, which disappeared at a 1:25 dilution. However, as shown in Fig. 4, extracts from ileostomy samples pooled over the time points from human subjects fed either milk or CPP preparations markedly inhibited the binding even at a dilution greater than 1:625. In agreement with results from HPLC and thin-layer electrophoresis analyses (Table 1), greater inhibition (at least a 100-fold difference) was observed for ileostomy samples obtained from human subjects fed milk as opposed to CPP.

\section{Discussion}

The reverse-phase HPLC peptide patterns (samples pooled over the time points $t 1-5$ ) were not characteristic of the test meal ingested, and complex elution profiles were also obtained in the fasting state $(t 0)$. Therefore, it would appear that the reverse-phase HPLC profiles also contained many endogenous components secreted into the intestinal fluid.

CPP were detected in ileostomy fluid obtained from human volunteers using two separate approaches, i.e. using HPLC analysis (in combination with peptide-bound 
Table 1. Identification of phosphopeptides in pooled ileostomy fluid collected for $10 \mathrm{~h}$ at $2 \mathrm{~h}$ intervals $(t 1-5)$ after ingestion of a test meal ${ }^{\star}$

\begin{tabular}{|c|c|c|c|c|c|}
\hline \multirow[b]{2}{*}{ Ileostomy sample† } & \multicolumn{2}{|c|}{ Peptide-bound P (HPLC)‡ } & \multicolumn{2}{|c|}{ Peptide-bound SerP } & \multirow{2}{*}{$\begin{array}{l}\text { Immunoreactive CPP } \\
(\mathrm{EIA} ; \mathrm{nmol} / \mathrm{mg}) \uparrow\end{array}$} \\
\hline & $\mathrm{nmol} /$ fraction & Fraction no. & TLE (ninhydrin-positive spot)§ & AAA $(\mathrm{nmol} / \mathrm{mg}) \|$ & \\
\hline \multicolumn{6}{|l|}{ Subject 1} \\
\hline 01-01:CPP2 & nd & nd & nd & nd & 0.05 \\
\hline 01-02:Milk & 8 & $12-14$ & + & $7 \cdot 3$ & $7 \cdot 10$ \\
\hline & 36 & $26-32$ & & & \\
\hline \multicolumn{6}{|l|}{ Subject 2} \\
\hline 02-01:CPP4 & nd & nd & nd & nd & 0.09 \\
\hline 02-02:Milk & 15 & $5-8$ & + & 4.8 & 4.40 \\
\hline & 11 & $12-15$ & & & \\
\hline & 3 & 21 & & & \\
\hline \multirow{2}{*}{\multicolumn{6}{|c|}{ Subject 3}} \\
\hline & & & & & \\
\hline 03-01:Milk & 7 & $28-29$ & + & $3 \cdot 1$ & $2 \cdot 60$ \\
\hline 03-02:CPP1 & nd & nd & nd & nd & 0.02 \\
\hline \multicolumn{6}{|l|}{ Subject 4} \\
\hline 04-01:Milk & nd & nd & + & $2 \cdot 8$ & $2 \cdot 60$ \\
\hline 04-02:СРP3 & nd & nd & nd & nd & 0.02 \\
\hline Pre-meal** & nd & nd & nd & nd & $<0.002$ \\
\hline
\end{tabular}

TLE, thin-layer electrophoresis; SerP, phosphoserine; AAA, amino acid analysis; EIA, enzyme immunoassay; CPP, caseinophosphopetide; nd, not detected.

${ }^{*}$ For details of subjects and test meals, see p. 352

†The soluble fraction obtained after extraction with perchloric acid (172 mM) was analysed. For details, see p. 352.

$\ddagger$ HPLC analysis and determination of total organically bound P in HPLC fractions.

$\S$ TLE of partial acid hydrolysates $(6 \mathrm{~h})$ and ninhydrin-positive spot of SerP.

\| AAA of acidic hydrolysates $(6,12,24 \mathrm{~h})$. SerP content per mg lyophilized ileostomy sample was obtained by extrapolation to zero time; non-hydrolysable material having the same elution position as SerP (equivalent to $\leq 0.5 \mathrm{nmol} / \mathrm{mg}$ ) was present in all samples; SerP was not detectable in the insoluble part of extracted ileostomy samples.

I Competitive EIA using rabbit (no. 1495) polyclonal antiserum and acetylcholinesterase-labelled synthetic phosphopeptide as tracer. CPP concentration equivalent to the amount of synthetic VESL $\Sigma \Sigma \Sigma E E S I L ~(\Sigma=$ SerP) per mg lyophilized ileostomy sample.

** The pre-meal sample represents a pool of all samples collected in the fasting state $(t 0)$.

$\mathrm{P}$ and SerP determination) of ileostomy extract, as well as the application of a unique EIA system. Both the immunochemical and chromatographic-peptide chemical approach to detect CPP enabled the semi-quantification of CPP in human ileostomy fluid of milk-fed volunteers (Table 1). However, the quantity of CPP in ileostomy samples from volunteers fed with CPP preparations was too small to be detected by HPLC or SerP analyses. The EIA system combined a broad specificity suitable for the detection of numerous different phosphopeptides and a high sensitivity that allows detection of trace amounts in complex media such as in biological fluids or food matrices.

The reason for looking at CPP generated with four different proteolytic preparations was that there were differences in the $\mathrm{Ca}^{2+}$ binding and solubilizing abilities of CPP in vitro depending on the enzyme preparation used in hydrolysate generation (McDonagh \& FitzGerald, 1998). However, this has not proved to be relevant in the current in vivo study. There is obviously an effect of the food matrix that protects CPP from degradation in the gut, provided that they are ingested as milk constituents and not as isolated CPP ingredients. CPP are not found naturally in good quality milk, but are encrypted in the primary structure of the caseins and are released by proteolytic action. Therefore, the form in which phosphopeptides exist in milk $v$. that in which they exist in the CPP meal is quite different, and this may account for potential differences in proteolytic susceptibility during gastrointestinal transit. It is worth noting that CPP released during milk digestion appeared to be stable for up to $8 \mathrm{~h}$ in ileostomy contents (Fig. 3). Milk seems to be a good 'wrapping' or 'carrier' for CPP, i.e. the corresponding protein-bound sequences are partly protected against proteolytic attack.

Based on the fact that the ingested amount of milk (250 g) is equivalent to $6.5 \mathrm{~g}$ casein, which accounts for $55 \mathrm{mg}$ $(1.775 \mathrm{mmol})$ organically bound $\mathrm{P}\left(\mathrm{P}_{\mathrm{o}}\right.$; Douglas et al. 1982), a maximal recovery of $15 \%$ peptide-bound $\mathrm{P}$ for the digestion products of milk can be estimated from the content of peptide-bound SerP (Table 1) multiplied by the total weight of freeze-dried ileostomy samples. Casein theoretically yields $126 \mathrm{mg} \mathrm{CPP/g}$, which is released predominantly during tryptic in vitro proteolysis (Meisel, 1998). This would suggest that about $120 \mathrm{mg}$ potentially available CPP could be liberated into the ileum after a meal of $250 \mathrm{~g}$ milk. This estimation is supported by an alternative calculation, which assumes that the CPP in ileostomy fluid have predominantly two SerP groups and that their average relative molecular mass was 1000 .

The Ca-binding constants for different CPP preparations are reported to be in the order of $10^{2}-10^{3} 1 / \mathrm{mol}$ (Berrocal et al. 1989; Sato et al. 1991; Meisel \& Olieman, 1998). Interestingly, the amount of Ca solubilized per mol CPP is far in excess of the estimated amount of SerP that binds an almost equivalent number of $\mathrm{Ca}^{2+}$. Accordingly, Berrocal et al. (1989) estimated that the effective CPP concentration required to inhibit the formation of insoluble $\mathrm{Ca}_{3}\left(\mathrm{PO}_{4}\right)_{2}$ in vitro was $10 \mathrm{mg} / \mathrm{l}$. Furthermore, it has been shown that relatively low concentrations of CPP $(10-50 \mathrm{mg} / \mathrm{l})$ can stimulate cultivated immunocompetent human cells (Hata et al. 1998, 1999). Therefore, it is postulated that the quantity of CPP found in ileostomy fluid in the present study could be of physiological importance. 


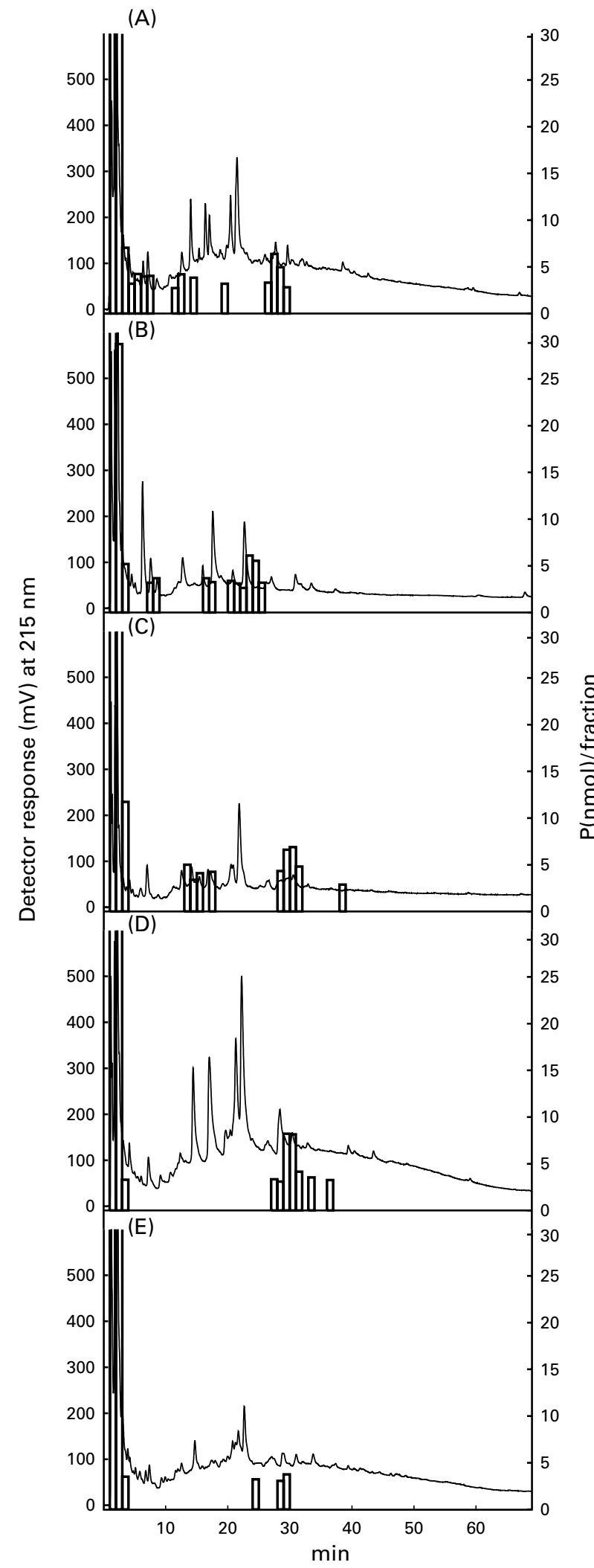

Fig. 3. HPLC peptide patterns and $P$ content of ileostomy fluids (perchloric acid-soluble fraction) measured at different time points post-dose ( $2 \mathrm{~h}$ intervals $t 1-5)$ after ingestion of a milk meal (subject 2 milk). (A), $t 1-5$ (pooled samples $2-10 \mathrm{~h}$ ); (B), $t 1$ (2h); (C), $t$ $3(6 \mathrm{~h}) ;(\mathrm{D}), t 4(8 \mathrm{~h}) ;(\mathrm{E}), t 5(10 \mathrm{~h})$. For details of subjects and test meals, see p. 352 .
(A)

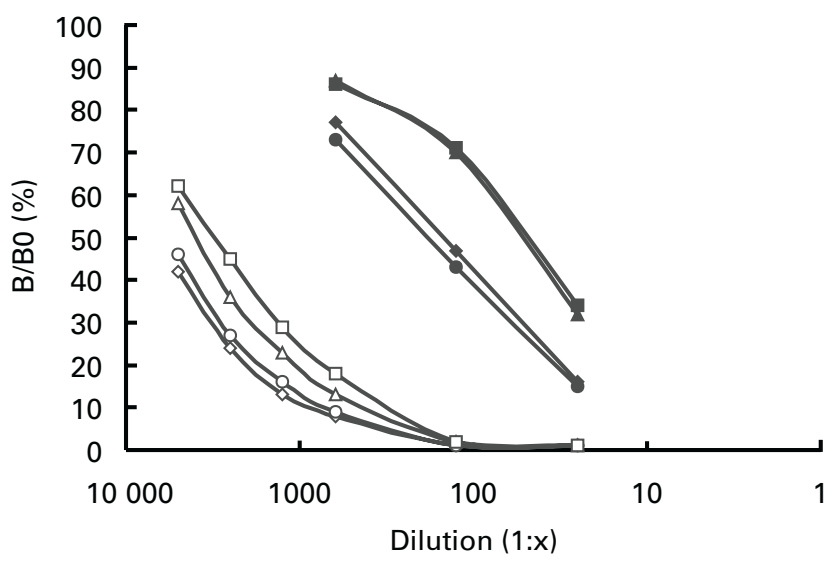

(B)

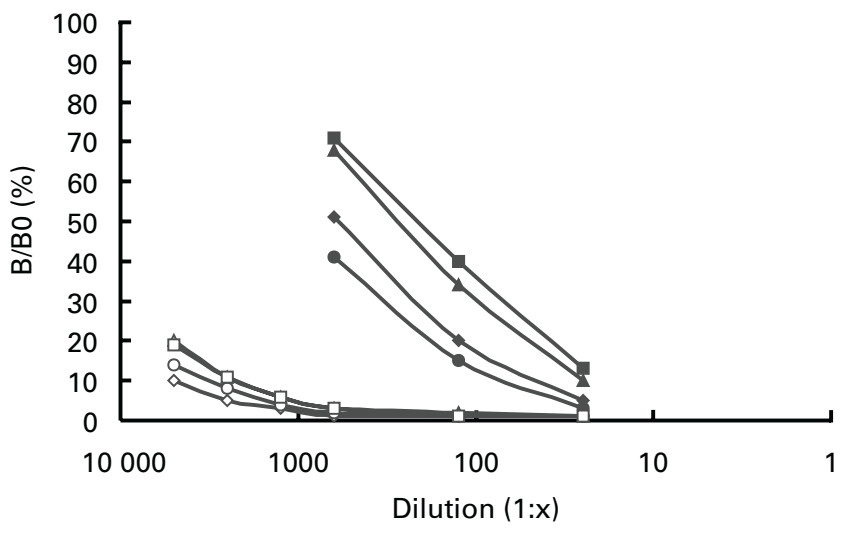

Fig. 4. Inhibition of the binding of specific rabbit anti-caseinophosphopeptides (CPP) antibodies (A, rabbit no. 1494; B, rabbit no. 1495) to synthetic phosphopeptide VESL $\Sigma \Sigma \Sigma E E S I L-a c e t y l c h o l-$ inesterase, where $\Sigma$ is phosphoserine) by different ileostomy samples from four human volunteers after ingestion of a milk meal ( $\diamond$ 01-2:Milk; $\bigcirc$ 02-2:Milk; $\square$ 03-1:Milk; $\triangle$ 04-1:Milk) and CPP meal $(\bullet 1-1: C P P 2 ; \bullet 02-1: C P P 4 ; \boldsymbol{\square} 03-2: C P P 1 ; \Delta$ 04-2:CPP3). The $y$-axis represents the bound enzyme activity in presence (B) or absence (B0) of competitor. For details of subjects and procedures, see p. 352.

The in vivo formation of CPP derived from bovine casein was demonstrated in the small intestinal fluid of minipigs after ingestion of a diet containing casein (Meisel \& Frister, 1988). Chabance et al. (1998) recently detected CPP in the stomach and duodenum of adult human subjects after ingestion of milk or yogurt. Our present studies demonstrate, for the first time, that phosphopeptides can survive the prolonged intestinal passage to the distal small intestine (ileum) in vivo, which is a prerequisite for their function as bioactive substances. Vitamin D-independent paracellular transport of $\mathrm{Ca}$ is known to play a major role in maximal passive $\mathrm{Ca}$ absorption from the distal small intestine (Bronner, 1987). However, the physiological significance of CPP as potentially bioactive substances in the ileum has not yet been clarified. Preliminary results indicate that consumption of CPP by human subjects does not significantly increase the fractional absorption of dietary Ca (B Teucher, G Majsak-Newman, JR Dainty, 
D McDonagh and S Fairweather-Tait, unpublished observations). Nevertheless, it has recently been demonstrated that CPP mediate $\mathrm{Ca}$ uptake in rat intestinal everted sacs (Erba et al. 2001) and into epithelial (HT29) cells (Ferraretto et al. 2001). Furthermore, the production of immunoglobulin $\mathrm{G}$ was stimulated by $\mathrm{CPP}$ in immunocompetent human cells (Hartmann et al. 2000). The latter finding is in support of the suggestion (Hata et al. 1998; Otani et al. 2000) that CPP may act as immunostimulators, which are beneficial to the enhancement of mucosal immunity. Therefore, irrespective of their possible function as $\mathrm{Ca}$ carriers, CPP are of particular interest as dietary components that may modulate specific bodily functions and thus have functional food ingredient potential for promoting better health and reducing the risk of developing specific diseases.

\section{Acknowledgements}

The studies have been carried out with financial support from the Commission of the European Communities, Agriculture and Fisheries (FAIR) specific RTD programme, CT98-3077, 'Caseinophosphopeptides: Nutraceutical/Functional Food Ingredients for Food and Pharmaceutical Applications'; the present publication does not necessarily reflect its views and in no way anticipates the Commission's future policy in this area.

\section{References}

Adamson NJ \& Reynolds EC (1995) Characterisation of tryptic casein phosphopeptides prepared under industrially relevant conditions. Biotechnology and Bioengineering 45, 196-204.

Berrocal R, Chanton S, Juillerat MA, Pavillard B, Scherz J-C \& Jost R (1989) Tryptic phosphopeptides from whole casein: II. Physicochemical properties related to the solubilisation of calcium. Journal of Dairy Research 56, 335-341.

Borgström B, Dahlqvist A, Lundh G \& Sjövall J (1957) Studies of intestinal digestion and absorption in the human. Journal of Clinical Investigation 36, 1521-1536.

Bronner F (1987) Intestinal calcium absorption: Mechanisms and applications. Journal of Nutrition 117, 1347-1352.

Brule G, Roger L, Fauquant J \& Piot M (1982) Phosphopeptides from casein-based material. U. S. Patent, No. 4,358,465.

Caruelle D, Grassi J, Courty J, Groux-Muscatelli B, Pradelles P, Barritault D \& Caruelle JP (1988) Development and testing of radio and enzyme immunoassays for acidic fibroblast growth factor. Analytical Biochemistry 173, 328-339.

Chabance B, Marteau P, Rambaud JC, Migliore-Samour D, Boynard M, Perrotin P, Guillet R, Jollès P \& Fiat AM (1998) Casein peptide release and passage to the blood in humans during digestion of milk or yogurt. Biochimie 80, 155-165.

Douglas FW, Tobias J, Groves ML, Farrell HM \& Edmondson LF (1982) Quantitative determination of total protein, casein, and whey protein of processed dairy products. Journal of Dairy Science 65, 33-45.

Ellman GL, Courtney KD, Andres V \& Featherstone RM (1961) A new and rapid colorimetric determination of acetylcholinesterase activity. Biochemical Pharmacology 7, $88-95$.

Erba D, Ciappellano S \& Testolin G (2001) Effect of caseinphosphopeptides on inhibition of calcium intestinal absorption due to phosphate. Nutrition Research 21, 649-656.

Ferraretto A, Signorile A, Gravaghi C, Fiorilli A \& Tettamanti G (2001) Casein phosphopeptides influence calcium uptake by cultured human intestinal HT-29 tumor cells. Journal of Nutrition 131, 1655-1661.

FitzGerald RJ (1998) Potential uses of caseinophosphopeptides. International Dairy Journal 8, 451-457.

FitzGerald RJ \& Meisel H (2000) Milk protein-derived peptide inhibitors of angiotensin-I-converting enzyme. British Journal of Nutrition 84, Suppl. 1, 33-37.

Hartmann R, Günther S, Martin D, Meisel H, Pentzien A-K, Schlimme E \& Scholz N (2000) Cytochemical model systems for the detection and characterization of potentially bioactive milk components. Kieler Milchwirtschaftliche Forschungsberichte 52, 61-85.

Hartmann R \& Meisel H (2002) Cytochemical assessment of phosphopeptides derived from casein as potential ingredients for functional food. Nahrung/Food 46, 427-431.

Hata I, Higashiyama S \& Otani H (1998) Identification of a phosphopeptide in bovine $\alpha_{\mathrm{S} 1}$-casein digests as a factor influencing proliferation and immunoglobulin production in lymphocyte cultures. Journal of Dairy Research 65, 569-578.

Hata I, Ueda J \& Otani H (1999) Immunostimulatory action of a commercially available casein phosphopeptide preparation, CPP-III, in cell cultures. Milchwissenschaft 54, 3-7.

McDonagh D \& FitzGerald RJ (1998) Production of caseinophosphopeptides (CPP) from sodium caseinate using a range of commercial protease preparations. International Dairy Journal 8, 39-45.

Meisel H (1997) Biochemical properties of regulatory peptides derived from milk proteins. Biopolymers 43, 119-128.

Meisel H (1998) Overview on milk protein-derived peptides. International Dairy Journal 8, 363-373.

Meisel H (2001) Bioactive peptides from milk proteins: a perspective for consumers and producers. Australian Journal of Dairy Technology 56, 83-92.

Meisel H, Bernard H, Fairweather-Tait S, FitzGerald RJ, Hartmann R, Lane CN, McDonagh D, Teucher B \& Wal J-M (2001) Letter to the Editor: Nutraceutical and functional food ingredients for food and pharmaceutical applications. British Journal of Nutrition 85, 635 .

Meisel H \& FitzGerald RJ (2000) Opioid peptides encrypted in intact milk protein sequences. British Journal of Nutrition 84, Suppl. 1, 27-31.

Meisel H \& Frister H (1988) Chemical characterization of a caseinophosphopeptide isolated from in vivo digests of a casein diet. Biological Chemistry Hoppe-Seyler 369, 1275-1279.

Meisel H \& Olieman C (1998) Estimation of calcium binding constants of casein phosphopeptides by capillary zone electrophoresis. Acta Chimica Acta 372, 291-297.

Otani H, Kihara Y \& Park M (2000) The immunoenhancing property of a dietary casein phosphopeptide preparation in mice. Food and Agricultural Immunology 12, 165-173.

Sato R, Shindo M, Gunshin H, Noguchi T \& Naito H (1991) Characterisation of phosphopeptide derived from bovine $\beta$-casein: An inhibitor to intra-intestinal precipitation of calcium phosphate. Biochimica et Biophysica Acta 1077, 413-415. 